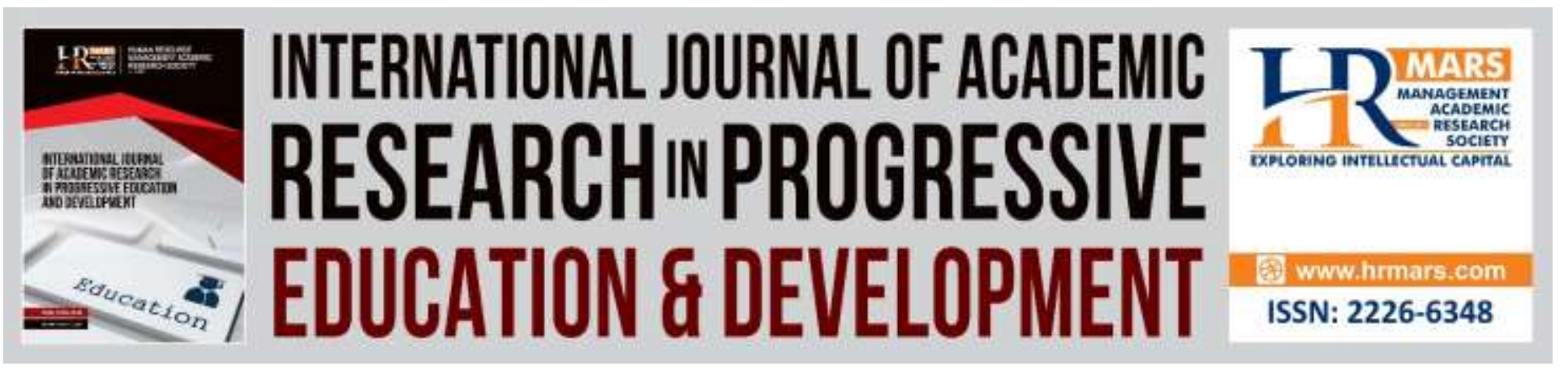

\title{
The Character of Quranic Surahs as a Tool of Understanding Quran Based on Sayyid Qutb S Point of Views
}

\author{
Husna Husain, Wahibah Hj. Tahir@Twahir
}

To Link this Article: http://dx.doi.org/10.6007/IJARPED/v8-i2/5913

DOI: 10.6007/IJARPED/v8-i2/5913

Received: 11 Jan 2019, Revised: 19 Feb 2019, Accepted: 01 March 2019

Published Online: 23 March 2019

In-Text Citation: (Husain \& Tahir@Twahir, 2019)

To Cite this Article: Husain, H., \& Tahir@Twahir, W. H. (2019). The Character Of Quranic Surahs As A Tool Of Understanding Quran Based On Sayyid Qutb S Point Of Views. International Journal of Academic Researchin Progressive Education and Development, 8(2), 341-348.

Copyright: (C) 2019 The Author(s)

Published by Human Resource Management Academic Research Society (www.hrmars.com)

This article is published under the Creative Commons Attribution (CC BY 4.0) license. Anyone may reproduce, distribute, translate and create derivative works of this article (for both commercial and non-commercial purposes), subject to full attribution to the original publication and authors. The full terms of this license may be seen

at: http://creativecommons.org/licences/by/4.0/legalcode

Vol. 8(2) 2019, Pg. 341 - 348

http://hrmars.com/index.php/pages/detail/IJARPED

JOURNAL HOMEPAGE

Full Terms \& Conditions of access and use can be found at http://hrmars.com/index.php/pages/detail/publication-ethics 


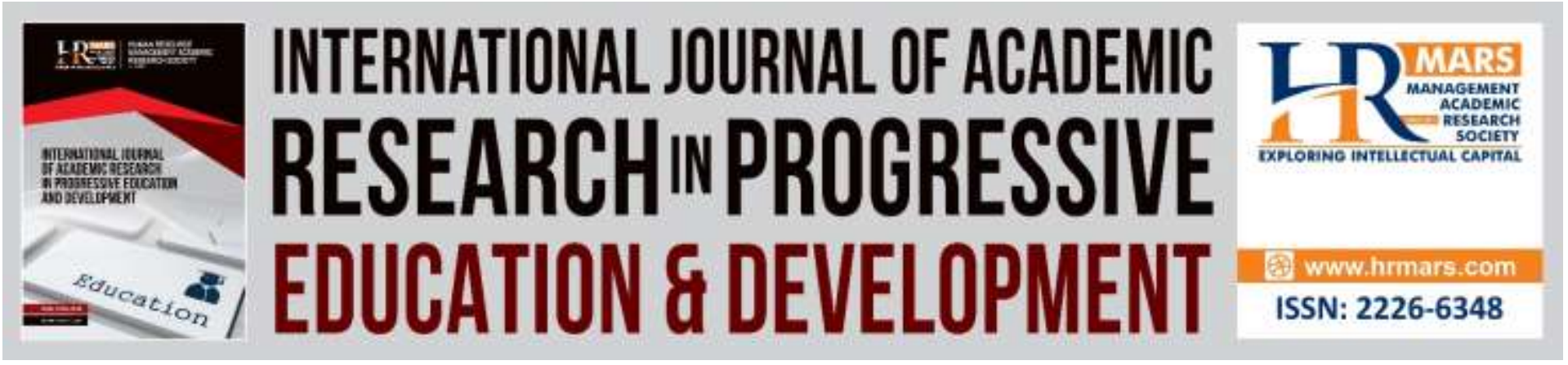

\title{
The Character of Quranic Surahs as a Tool of Understanding Quran Based on Sayyid Qutb S Point of Views ${ }^{1}$
}

\author{
Husna Husain, Wahibah Hj. Tahir@Twahir \\ Department of Islamic Studies, Faculty of Human Sciences, Universiti Pendidikan Sultan Idris, \\ anjong Malim, Perak, Malaysia. \\ Email: husnahusain@fsk.upsi.edu.my
}

\begin{abstract}
Qutb (1966) is among the mufassirun or commentators of the Quran who gives emphasis on the aspects of thematic coherent or al-wihdah al-mauduiyyah in Quranic surah in his exegesis book of Tafsir Fi Zilal al-Quran. At the same time, he also associates the thematic coherent with the term syakhsiyyah al-surah or the characteristic of Quranic surahs which is repeated several times in the tafsir apparently, emphasises a meaningful and conceptual term. This article is intended to clarify the concept of the term characteristic of Quranic surahs according to Sayyid Qutbs point of views in his book Tafsir Fi Zilal al-Quran. This study is a qualitative method of analysis of the data obtained from the primary and secondary sources of documents. The result shows that the term characteristic of Quranic Surahs or syakhsiyyah al-surah has a wider context than the thematic coherent or al-wihdah al-mauduiyyah, and states the benefits for the readers of the Quran because it is considered as a valuable tool to help them understanding the Quran comprehensively and efficiently.
\end{abstract}

Keywords: Characteristic of Quranic surahs, thematic coherent, Sayyid Qutb, understanding Quran.

\section{Introduction}

Sayyid Qutb or his real name Sayyid Qutb Ibrahim Husain Shazili is among the influential commentators of tafsir in Arab countries, and all over the world in the 20th century. He was born in 1906 in the village of Musyah in the district in Asyut, Egypt. He grew up in a family that put high concern on Islamic education with the children. Therefore, since a child he has been taught about the Quran, hence he memorized the Quran before the age of eleven years.

\footnotetext{
1 Acknowledgement: This research was funded by Sultan Idris Education University, research code: GPU 2016-0034-106-01.
} 
INTERNATIONAL JOURNAL OF ACADEMIC RESEARCH IN PROGRESSIVE EDUCATION AND DEVELOPMENT

Vol. 8, No. 2, 2019, E-ISSN: $2226-6348$ @ 2019 HRMARS

The story of Sayyids life, his struggles, and thoughts were clearly visible through his writings within three levels. The first level where the books initially focused on works of language and literature. Then it evolved to a writing related to the beauty, uniqueness, and inimitability of the language in the Quran, as an example; his book al-Taswir al-Fanniy fi al-Quran and Mashahid alQiyamah fi al-Quran. Next, the high level of glory and great influence through his writings and thoughts occured after his return from his stay in United States of America dated from 1948 to 1966. During the period, all his writings focused on the message of islah and tajdid, social justice in Islam and jihad. The work, which considered being his magnum opus, is Tafsir Fi Zilal al-Quran that had been translated into many languages in the world and published repeatedly. In addition to Tafsir Zilal, other works such as al-Adalah al-ljtimaiyyah fi al-Islam, the book of Hadha al-Din and Maalim fi al-Tariq had also attracted people (Al-Khalidi, 2012).

\section{The Thematic Coherent Concept or al-wihdah al-mauduiyyah in Tafsir Fi Zilal al-Quran}

Tafsir Fi Zilal al-Quran is known by the application of the thematic coherent concept or al-wihdah al-mauduiyyah in the Quran. In addition, this concept has a close relation with syakhsiyyah al-surah or characteristic of Quranic surahs, which is the focus of this paper. The concept of thematic coherent according to Sayyid Qutb, states that the Quran in its entirety shows a similar theme and is interconnected. Each surah also owns the central theme as well as the link between the verses with other verse in the same surah (Husain, 2015).

According to Muttalib (1986), al-Rumi (1997), Zarzur (1998) and Salah Al-Khalidi (2012), Qutb is the first Quran commentator who developed and applied the concept of thematic coherent in his book of tafsir. Despite previous Quran commentators who talked about this concept, such as Fakhruddin al-Razi $(\mathrm{M} 606 \mathrm{H})$ and al-Biqaiy $(\mathrm{M} 885 \mathrm{H})$, the application of the concept was not done in their tafsir book clearly and consistently as was done by Sayyid Qutb in the Tafsir Fi Zilal al-Quran.

According to Al-Khalidi (2012), he argued that Tafsir Fi Zilal al-Quran has an excellent performance in Quranic exegesis, which emphasises its strength in featuring the concept of alwihdah al-mauduiyyah or thematic coherent of the Quran in his interpretation of the style and language of its own. Al-Rumi (1997) also stated that Qutb had his standard and particular formulation in interpreting Quranic verses. Therefore, it is clearly shown that Qutb was extremely focused on the use of the thematic coherent on applying to the foundation of values of the Quran itself, where he concluded that the Quran and the rest of its contents aim to build human beliefs and creed. This goal is because such acts and human behaviors are direct results of one's belief and creed, which is the thematic coherent of the Quran as a whole, according to Qutbs point of views.

Qutb found that each surah has a consistent theme, which he had defined as mihwar. Each theme of Quranic surahs diverses to other topics that he called as maqta, while maqta constitutes the smaller topic or juziyyat. For Qutb, all the elements are built in a perfect order and decent which create the beauty of the Quranic language. Therefore, Salah Al-Khalidi concludes that Sayyid Qutb s thematic coherent concept in his book Tafsir Fi Zilal al-Quran includes the following aspects;

1. The coherence (munasabat) between Quranic surahs.

2. The coherence (munasabat) between teachings (durus) in a surah which make the theme (mihwar) of each surah.

3. The coherence (munasabat) between topics (maqta) in the same teaching (durus).

4. The coherence (munasabat) between Quranic verses on the same topic (maqta). 
INTERNATIONAL JOURNAL OF ACADEMIC RESEARCH IN PROGRESSIVE EDUCATION AND

DEVELOPMENT

Vol. 8, No. 2, 2019, E-ISSN: 2226-6348 @ 2019 HRMARS

5. The coherence (munasabat) between the words or phrase in the same verse.

\section{The Character of Quranic Surahs Based on Sayyid Qutbs Point of Views}

Among contemporary scholars of tafsir such as Qutb (2004), Said Hawwa, Dr. Faḍl Hassan Abbas (1985) and Mustafa Muslim (2005) introduce the term syakhsiyyah al-surah in their works. However, Sayyid Qutb was seen more frequently and consistently used the term in his book than others, in particular in the introduction of each surah. At a glance, this term is understood as a coherent or relation of themes in a surah. But in a particular investigation through Tafsir Fi Zilal alQuran, the term is seen as possessing wider meaning and concept than that. Also, the term is less discussed by the scholars of tafsir and Quranic studies, thus showing as if the topic is not important, whereas anything that contributes to the understanding of the Quran is important.

The word (شخصية) is derived from the word (شخص) which means personality or appearance in front of others (Manzur, 1992). The combination of word (شخصية) and the word (السورة) means appearance or personality of Quranic surah from other chapters. Thus, it can be understood when one chapter has a character, it shows it has a personality and privileges of its own. The question is what is meant by syakhsiyyah al-surah, and what are the aspects, which build character and distinctive in every surah in the Quran?

In this case, an in-depth analysis has been done towards Tafsir Fi Zilal Quran to see the use of the phrase syakhsiyyah al-surah in the book to identify the meaning, thus identifying those aspects that build syakhsiyyah al-surah. Steps were taken starting with finding the word syakhsiyyah al-surah or word syakhsiyyah. Then the author analysed the topics discussed around the word. In addition, each Muqaddimah for each chapter in Tafsir Fi Zilal al-Quran was also analysed to gain information and insight into the meaning of this concept. Based on the observation and analysis from the data obtained, these following points were identified;

1. The definition of syakhsiyyah al-surah is broader and general than the thematic coherent concept or al-wihdah al-mauduiyyah. Sayyid Qutb also referred it as a word mihwar, maudu and ghayah. He stated consistently in every introduction of each surah that every single chapter or surah of al-Quran has its personality. This is based on the following points:

i. Sayyid Qutb represented the chapters of the Quran by God the Almighty, based on the point of a human being that each has its personality and privileges. Every person has the biological characteristics of being human, but are not similar in various angles such as, trait and nature. So is the case with chapters of the Quran, which each chapter has the privilege and the differences in compared to one another.

ii. There are some statements from Sayyid Qutb indicated that syaksiyyah al-surah does not mean al-wihdah al-mauduiyyah.

"Anyone who studies the Quran closely, and tastes the unique and wealth of experience of living within its ambiance, will immediately identify the distinct character of every one of its surahs. Every surah has an aura and a personality of its own, with unique and welldefined features, and a feel that makes it stand apart from all the rest. Moreover, every surah revolves around a central theme or some major themes related to one another by a common thread or idea. Every surah radiates its atmosphere of meaning and essence, within which its theme, or themes, are discussed using the same well-integrated and well- 
INTERNATIONAL JOURNAL OF ACADEMIC RESEARCH IN PROGRESSIVE EDUCATION AND DEVELOPMENT

Vol. 8, No. 2, 2019, E-ISSN: 2226-6348 @ 2019 HRMARS

coordinated style and approach. It also has its distinctive rhythm and musical pulse, which accord with the meaning and context of its topics and content... "(Sayyid Qutb, 2004).

"And not a theme (mihwar) which determine syakhsiyyah of a chapter, but it is determined by the specific signs and characteristics to a chapter." (Sayyid Qutb, 2004)

Another prominent statement of Sayyid Qutb is:

"Each chapter has its own maudu and ghayah (mihwar). Then it has different characteristics from other chapters, apart method of delivery and specific aspects to convey a theme (mihwar) and accentuating the goals of a chapter."

His first and second statement are stated that syakhsiyyah al-surah does not mean al-wihdah almauduiyyah; he even associates syakhsiyyah al-surah with other signs in the chapter. While the third statement indicates that al-wihdah al-mauduiyyah are parts of the aspects that build syakhsiyyah al-surah.

Key aspects of constructing syakhsiyyah al-surah is a relation or munasabat between chapters or verses in the Quran.

As mentioned earlier, syahsiyyah al-surah is not al-wihdah al-mauduiyyah. However, al-wihdah almauduiyyah, which is based on the science of munasabat, are the key aspects that make up the personality of a Surah. For example, in the introduction of Yunus, Qutb stated the mihwar equation of this Surah with Surah al-Anam, which in both chapters present about the nature of the true creed and its role in facing ignorance that distorts the faith, worship, and human practices. However, the presentation and tones resulting from the choice of words and its arrangement make Surah al- Anam firmer and thriller. Whereas the strains of Surah Yunus has softer pronouncement and is soothing although both surahs share the same theme.

Nevertheless, Surah al-Araf, the surah after al- Anam has a similar theme with Surah Hud, which ranked in the Quran after Surah Yunus. Union themes that shared between both chapters are to explain the movement and spread of Islamic faith throughout the stories of the Prophets which deal with the ignorance of their people. According to Qutb, both of these chapters shared the same tone of presentation in paragraph, pulsating rhythm and similar movement.

From the example above, this clearly shows how Qutb associate munasabat between the chapters and verses with different styles as to show that each chapter has its personality.

3. Other aspects that make up syakhsiyyah al-surah was Jaww al-surah or the unique atmosphere when a chapter or verse is revealed.

The meanings that Sayyid Qutb stressed on Jaww al-surah or unique atmosphere refers to two conditions. First, Jaww al-surah, which based on the unity theme or mihwar of the chapter as described in the previous aspect. Secondly, jaww al-surah which related with the cause of nuzul ayat, as well as knowledge of science madaniyy and makkiyy. The fact that knowing whether the verse is makkiyah or madaniyyah is vital in helping the interpretation of a verse. At the same time, Qutb brings the reader's attention that the reader can understand the situation and the prevailing circumstances, as well as to emphasize the emotions involved at the time. This situation justifies a close relationship between the union themes of the surah with a particular atmosphere of the sentences revealed.

For example in introduction of Surah Yusuf, Sayyid Qutb wrote as follows; 
INTERNATIONAL JOURNAL OF ACADEMIC RESEARCH IN PROGRESSIVE EDUCATION AND DEVELOPMENT

Vol. 8, No. 2, 2019, E-ISSN: 2226-6348 @ 2019 HRMARS

"The surah is a single, complete unit with an apparent Makkan character reflected in its subject matter, message and ambiance. It reflects the nature of the critical period in which it was revealed. The Prophet was enduring a time when he felt lonely and alienated from his social surroundings, and his followers felt the strains of isolation. With the revelation of this surah, God tells His noble Messenger, Muhammad, the story of a devoted brother, one Joseph Ibn Jacob Ibn Isaac Ibn Abraham, (peace be upon them all). Joseph too had to endure a series of tests and trials: first, his brothers schemed to get rid of him, then he was thrown into the well where he found himself in fear of his life. Later on followed by his becoming a slave sold like an inanimate object, having no say in the matter and losing all the care and love of his parents. He then faced temptation and seduction, followed by the wicked scheming of his master's wife and her fellow women. He then had to endure long imprisonment after having lived comfortably in a palace." (Qutb, 2004)

4. Other aspects that make up syakhsiyyah al-surah is iqa musiqiyy or a particular ringing sound. What is meant by iqa musiqiyy or unique rhythm and musical pulse are not like a musical rhythm that some people understand. However, what is meant by Qutb was a compatibility tone produced from the selection of the word and its position in the same paragraph where there is a repetition of the same letter, repeating the same word sound, as well as repeating words sound almost identical. Compatibility and mesmerizing beauty of this sound attracting interest and admiration the hearts of the Arabs such as al-Walid bin Mughirah and others, so that al-Walid al-Quran says it's a magic because the integration and coordination are beyond human ability.

This aspect posed by Qutb in his book al-Taswir al-Fanniy fi al-Quran, in which he stated that, the language of the Quran and His threaded words are completely free from the shackles of rhyme and Arabic poetry. The word and the language style of the Quran are also independent of the general objectives contained in rhyme and verse. The rhythm of the language of the Quran does not require forms such as poetry or rhyme because it has special privileges that go beyond the beauty of Arabic poetry.

As an example of how Qutb connects iqa musiqiyy or unique rhythm sound with the thematic coherent of the surah that makes up its character, as stated in the introduction of Surah Ghafir;

"The whole atmosphere of a surah is one of a battle, the battle between truth and falsehood, faith and tyranny. This is interspersed with an air of grace and mercy whenever the believers are mentioned. The general atmosphere through a description of how earlier communities were destroyed as a result of their opposition to Divine faith, as well as several images of the day of judgment. All in all, these awesome images suit the somber air of the surah. Fittingly, the opening of the surah uses short phrases that carry a distinctive beat;

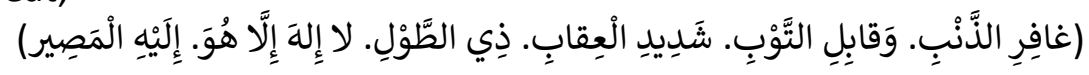

These phrases sound like a hammer striking in unison, with harmony between meaning and rhythm. Note also that words like might and power are frequently used in the surah."

Furthermore, Sayyid Qutb also argues that what is meant by iqa musiqiyy is a manifestation of alIjaz al-Bayani, which relates to the concept of Nazm al-Quran. Nazm al-Quran is a set of words in a sentence, with the right words and correct order that raises coordination, compatibility, and link among all words, verses, and surahs having the same nature (Al-Biqai, 1995). As a result, this draw 
INTERNATIONAL JOURNAL OF ACADEMIC RESEARCH IN PROGRESSIVE EDUCATION AND DEVELOPMENT

Vol. 8, No. 2, 2019, E-ISSN: 2226-6348 @ 2019 HRMARS

attention and feelings of the Quran as a complete unit. According to Al-Jurjani (2004), he stressed that different sentence structure would bring change to the meaning of a sentence.

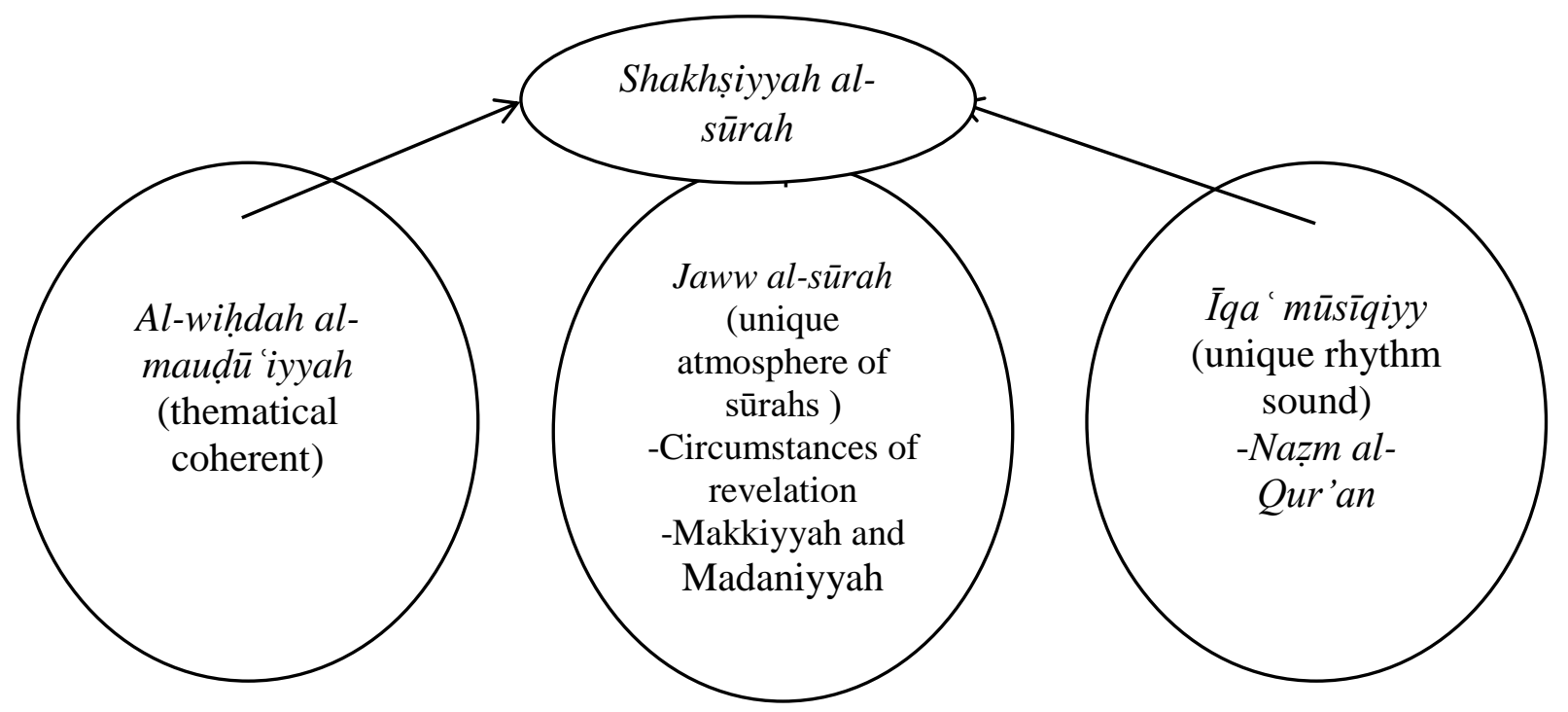

The concept of syakhsiyyah al-surah on Sayyid Qutb s point of view

\section{Conclusion}

The basic concept of interpretation in Fi Zilal Al-Quran is to provide an overview or display that can be described and felt by the readers of the Quran so that they can experience the message, then adopts its contents. Thus, we find that he presented an overview of the interpretation through the thematic coherent concept or al-wihdah al-mauduiyyah, which forms a unique character of every surah in the Quran. However, syakhsiyyah al-surah does not mean al-wihdah al-mauduiyyah, even though it is more common than al-wihdah al-mauduiyyah. Drawing from the aspects form syakhsiyyah al-surah anchored by al-wihdah al-mauduiyyah itself, accompanied by Jaww al-surah based on the circumstances of the revelation, it is a challenge to identify whether it is a Makkan surah or Madaniyyah. Along with that, syakhsiyyah al-surah is also shaped by the beauty of the language, which combines the selection of the right word and position in the sentence that matches the theme of a surah, which discloses an audible tone that can affect the readers emotions as well.

The concept of syakhsiyyah al-surah is a development and an enhancement of thematic coherent that focuses on the meaning and the essence of particular surahs in the Quran. Hence, the application of this concept to the whole Quranic verses is a matter that can lead to a new dimension in understanding the essence of the Quran itself. In addition, this concept actually combines the ideas that have been preached by previous or contemporary scholars with Sayyid Qutb such as AlBiqai, Al-Razi and Hamiduddin Farahi. Syakhsiyyah al-surah concept is very helpful to the reader of the Quran to obtain knowledge on the background and uniqueness of the surah and simplifies the process of tadabbur that occurs. 
INTERNATIONAL JOURNAL OF ACADEMIC RESEARCH IN PROGRESSIVE EDUCATION AND DEVELOPMENT

Vol. 8, No. 2, 2019, E-ISSN: 2226-6348 @ 2019 HRMARS

\section{References}

Zarzur, M. A., (1998). Madkhal Ila Tafsir al-Quran wa Ulumih. Damsyiq: Dar al-Qalam.

Al-Jurjani, A. Q., (2004). Dalail al-ljaz, c. 5. Kaherah: Maktabah al-Khanji.

Al-Khalidi, S. (2012). Sayyid Qutb al-Shahid al-Hayy. c. 1. Amman: Maktabah al-Aqsa.

Al-Rumi, F. (1997). Ittijahat al-Tafsir fi al-Qarn al-Rabi. Beirut: Muassasah al-Risalah.

Abbas. F. H., (2010). Itqan al-Burhan fi Ulum al-Quran. Amman: Dar al-Nafais, cet. 2.

Husain, H. (2015). Ara Sayyid Qutb Fi Qaḍaya al-Marah min Khilal Tafsir Fi Zilal al-Quran. Unpublished Ph.D. thesis from Jordan University.

Ibn Manzur, M., (1992). Lisan al-Arab. c. 3. Beirut: Dar Sadir.

Khan, I. A., (2002). Coherence in the Quran: Principles and Applications: Intellectual Discourse. International Islamic University Malaysia,10 (1), 47-60.

Rahim, A. M. H. (2013). Munasabat al-Quran: Analisa Dari Aspek Keindahan dan Prospek Masa Hadapan. Jurnal Al-Bayan, Akademi Pengajian Islam Universiti Malaya, 11 (1), 66.

Darraz, M. A., (2005). Al-Naba al-Azim. Dar al-Qalam.

Qutb, S. (2004). Tafsir Fi Zilal al-Quran. cet. 34, Kaherah: Dar al-Shuruq.

Qutb, S. (1975). Al-Taswir al-Fanni fi al-Quran. Kaherah: Dar al-Maarif.

Muttalib, A. F. F. (1986). Al-wihdah al-mauḍiyyah li al-Surah al-Quraniyyah. Kaherah: Dar alSalam.

Salwa, M. S. \& El-Awa. (2006). Textual Relations in the Quran: Relevance, Coherence and Structure. New York: Routledge Taylor \& Francis Group.

Mulazamah, S. (2014). Konsep Kesatuan Tema al-Quran Menurut Sayyid Qutb. Journal of Quran and Hadith Studies, 3 (2), 203-234. 